\title{
GC-MS Compositional Analysis of Essential Oil of Leaf and Fruit Rind of Citrus maxima (Burm.) Merr. from Coastal Karnataka, India
}

\author{
D. Anupama Prasad ${ }^{1}$, B. Rajendra Prasad ${ }^{2}$, D. Krishna Prasad ${ }^{1}$, Puneeth Shetty ${ }^{3}$, K. N. Sunil Kumar ${ }^{4 *}$ \\ ${ }^{1}$ Department of Prosthodontics, Crown and Bridge, AB Shetty Memorial Institute of Dental Sciences, Nitte University, Deralakatte, Mangalore, D.K, India. \\ ${ }^{2}$ Department of Oral and Maxillogical Surgery, AB Shetty Memorial Institute of Dental Sciences, Nitte University, Deralakatte, Mangalore, D.K, India. \\ ${ }^{3}$ Department of Pharmaceutical Chemistry, SDM Centre for Research in Ayurveda and Allied Sciences, Laxminarayana Nagar, Kuthpady, Udupi, India. \\ ${ }^{4}$ Department of Pharmacognosy and Phytochemistry, SDM Centre for Research in Ayurveda and Allied Sciences, Laxminarayana Nagar, Kuthpady, Udupi, \\ India.
}

\begin{tabular}{l} 
ARTICLE INFO \\
\hline Article history: \\
Received on: 14/11/2015 \\
Revised on: 24/12/2015 \\
Accepted on: 19/01/2016 \\
Available online: 03/05/2016 \\
\hline Key words: \\
Citronellol, essential oil, \\
GCMS, herbal medicine, \\
hydro-distillation, limonene.
\end{tabular}

\begin{abstract}
Essential oils derived from plants by hydro distillation possess several medicinal properties. Citrus maxima (Burm.) Merr. fruit is nutritive, cardiotonic, refrigerant, in stomach troubles, puerperal sepsis and insanity; while leaves are useful in epilepsy, chorea, convulsive cough and stomach pain due to indigestion. Gas chromatography coupled with mass spectroscopy (GCMS) has been used for detection and identification of volatile components from the hydro-distillate from leaf and rind of Citrus maxima (Burm.) Merr. of Rutaceae. Yield of oil was more in rind $(0.12 \%)$ compared to leaf $(0.07 \%)$. Forty two and thirty four compounds were detected from leaf and fruit respectively, among which citronellol $(28.26 \%)$ was the major component in the leaves while D-limonene $(89.04 \%)$ in the rind. Volatile compounds responsible for various medicinal properties are identified from hydrodistillate of Citrus maxima (Burm.) Merr. from Dakshina Kannada using GC-MS.
\end{abstract}

\section{INTRODUCTION}

Due to the resistance developed by microbes to the commercially available antibiotics researchers are now concentrating on herbal remedies which have less side effects but more powerful in inhibiting the microbial colonization. The ovalshaped sacs in the flavedo or colored portion of the peel of many Citrus spp are the reservoirs of oils which are natural toxic barrier to many microorganisms. Terpenes from volatile oil of medicinal plants are reported to be powerful antimicrobial agents. Effect of DL-limonene in inhibition of cell growth, ethanol formation, and sugar utilization by $S$. cerevisiae has also been reported (Unal et al., 2012). Essential oil C. limonum and $C$. aurantium were effective in inhibition of microorganism growth in multi-species biofilms in the oral cavity, which included Candida albicans, Escherichia coli, and Enterococcus faecalis

\footnotetext{
* Corresponding Author

Dr. Sunil Kumar KN, Senior Research Officer, Department of Pharmacognosy and Phytochemistry, SDM Centre for Research in Ayurveda and Allied Sciences, Laxminarayana Nagar, Kuthpady, Udupi, India.Email:sunilkumarnarayanan@gmail.com
}

responsible for atrophic candidiasis, periradicular disease, endodontic infections and several other infections (Oliveira et al., 2014). Lemon fruit peels, seeds and juice also possess activity against bacteria like Streprococcus aureus and fungus $C$. albicans (Pandey et al., 2011). Citrus maxima (Burm.) Merr. syn. C. grandis (Linn.) Osbeck; C. decumana Linn. is spreading, roundtopped almost thorn less tree. The fruit is nutritive, cardiotonic and refrigerant. Leaves are useful in epilepsy, chorea and convulsive cough (Nadakrni, 1954; Chopra et al., 1956). The fruit juice is used in stomach troubles (Dagar and Dagar, 1996); puerperal sepsis and insanity (Bortahnkur, 1996). Leaves are used in stomach pain due to indigestion (Chaudhari and Pal, 1976).

With the above background information, an attempt has been made to find out chemical constituent of grapefruit leaf and fruit rind essential oil using GC-MS.

\section{MATERIAL AND METHODS}

\section{Plant Materials \\ Mature grapefruits and leaves were collected from Manjanady, Mangalore, Dakshina Kannada district Karnataka.}




\section{Instrumentation and Techniques}

Volatile oil in the drug is estimated by distilling the drug with a mixture of water and glycerin in a Clavenger's apparatus. The distillate was collected in a graduated tube in which the aqueous portion of the distillate is automatically separated and returned to the distilling flask. Volume of the oil collected on the surface of water in the graduated tube was measured. The content of the volatile oil is expressed as a percentage v/w. GC-MS was carried out using Shimadzu gas chromatograph with a SE-30 10\% Chromosorb-W packed stainless steel column $(2 \mathrm{~m} \quad \mathrm{x} 2$ $\mathrm{mm})$. Oven programme: $60^{\circ} \mathrm{C}(5 \mathrm{~min}), 60^{\circ}-260^{\circ} \mathrm{C}\left(5^{\circ} \mathrm{C} / \mathrm{min}\right)$, $260^{\circ} \mathrm{C}$ (10 min); carrier gas - nitrogen, flow rate $40 \mathrm{ml} / \mathrm{min}$; injector temperature $240^{\circ} \mathrm{C}$; detector temperature $240^{\circ} \mathrm{C}$. Individual components were identified by database of mass spectra matching with literature available in the libraries like NIST and WILEY by comparison of their mass spectrum values. The LRI of a compound is an expression of its retention time on a gas chromatographic column relative to an homologous series nalkanes. The following equation is used to calculate the Linear retention index (LRI) from the retention time (Adam, 1995).

$$
\text { LRI }=100\left(\frac{\mathrm{t}-\mathrm{t}_{\mathrm{n}}}{\mathrm{t}_{\mathrm{n}-1}-\mathrm{t}_{\mathrm{n}}}+\mathrm{n}\right)
$$

$\mathrm{t}=$ retention time of component

$\mathrm{n}=$ carbon number of preceding $\mathrm{n}$-alkane

$\mathrm{n}+1=$ carbon number of subsequent n-alkane

\section{RESULT AND DISCUSSION}

From $1500 \mathrm{~g}$ of leaves of grapefruit tree around $1 \mathrm{ml}$ $(0.07 \%)$ of pale white light volatile oil has been obtained by hydro-distillation using Clavenger's apparatus. Similarly, $1.5 \mathrm{ml}$ of pale white light volatile oil was obtained from $1250 \mathrm{~g}(0.12 \%)$ of fruit rind. The composition of the volatile oil was analyzed by GCMS. Fourty two constituents were detected from leaf, of which, 15 could not be identified as the mass fragmentation showed low similarity. Three major compounds eluted at RT 12.127, 14.481 and 21.014 mins were identified as $\beta$-Caryophyllene (16.89\%), (-)Spathulenol (9.32\%), and Citronellol (28.26\%) respectively. Other high concentration constituents were $\tau$-Cadinol (3.16), 1-Ethenyl1-methyl-2-(1-methylethenyl)-4-(1-methylethylidene) cyclohexane (2.66\%), $\alpha$-Cadinol (2.51\%), $\alpha$-Caryophyllene (2.48\%), 1-Bromo4-bromomethyl decane (2.43\%), 2-n-Hexylcyclopentanone (2.22\%). A major compound at RT 32.034 which accounted for $11.69 \%$ could no bet identified (Table 1 ).

Thirty four constituents were detected from fruit rind, of which, 10 could not be identified as the mass fragmentation showed low similarity index. Limonene was the major compound accounting for $89.04 \%$. Three other major compounds were $\beta$ Pinene $(2.25 \%), \beta$-Myrcene $(2.06 \%)$ and $\beta$-Copaene $(1.76 \%)$. All other compounds were found to be present in traces (Table 2).

Surprisingly, none of the identified compounds were found occurring in both leaf and rind, though both are from same botanical origin. The two different parts found to have distinguished chemical composition (Table 3). Antimicrobial resistance is increasing rapidly leading for the need to explore herbal remedies which does not have side effects. Thought was given to find out the components of the essential oil to explore Pomelo/Shaddock/Chakkotha, one of the fruits belonging to genus Citrus and commonly cultivated for consumption in Southern India, as a possible source of antimicrobial chemicals.

Composition of volatile oil of plants growing at different localities largely depends on the geographical conditions, and there are no studies in report on the composition of oil from this plant growing in Western Ghats. Leaf and fruit rind was considered for this study as volatile oil of Citrus species is mainly concentrated in these parts.

This result of the present study is similar to the few studies done on other species of Citrus in the past (Uysal et al., 2011; Droby et al., 2008; Kirbaşlar et al., 2009; Fuselli et al., 2008) where the major compounds detected were D-Limonene, $\beta$ myrene, $\alpha$-pinene, caryophyllene, octanal and $\beta$-phellandrene. Some of the minor components included $\delta$-cadinene, copaene, methyl phthalate, linalool and 3-carene. The compounds detected from leaves of orange (Citrus sinensis), bigaradier (Citrus aurantium), mandarin (Citrus limonum) and lemon (Citrus reticulata) were limonene $(7.18 \%), \beta$-pinene $(4.35-30 \%)$, and linalool (0.21-63.03\%), and these compounds were found to be effective against fungi and their spores (Uysal et al., 2011). The percentage yield of volatile oil is very less; the sample examined in the present study revealed $0.12 \%$ oil in fruit rind and $0.07 \%$ essential oil in leaves by hydro-distillation method employing Clavenger's apparatus. In a study on Algerian species of Citrus by Zohra et al., 2015, percentage yield of volatile oil from orange, lemon, mandarin and bigaradier were in the range of 0.96, 1.02, 0.51 and 0.73 respectively. Another study by Javed et al., 2014 reported a yield of $0.28-0.45 \%$, where Grapefruit, Malta, Mandarin, Mousami, and Tangerine respectively yielded $0.45 \%$, $0.37 \%, 0.33 \%, 0.30 \%, 0.28 \%$. The variation seen in the percentage yield may be due to the differences in climatic conditions, soil quality and methods of extraction. In several studies on citrus varieties, peel oil consisted of limonene as the most predominant component followed by $\beta$-myrcene, $\alpha$-pinene, $\beta$-phellandrene, 3 carene and nonane, $\beta$-pinene, $\gamma$-terpinene (Zohra et al., 2015; Okunuwo et al., 2013; Javed et al., 2014; Vasudeva and Sharma, 2012; Sorrou et al., 2013), another study (Takaya et al., 2008) on oil extract of peel of Citrus aurantium L. found $\beta$-pinene $(0.62 \%$ $19.08 \%)$, limonene $(0.53 \%-94.67 \%)$, trans- $\beta$-ocimene $(3.11 \%$ $6.06 \%)$, linalool $(0.76 \%-58.21 \%)$, and $\alpha$-terpineol $(0.13 \%-$ $12.89 \%$ ) as major components. In earlier studies on this plant, leaf oil is reported to contain $\alpha$-pinene, $(2.6 \%), \beta$-pinene $(6.6 \%)$, linalool $(42.34 \%)$ and linlyl acetate $(44.18 \%)$ (Nigam and Dutt, 1945; Nigam and Kumari, 1962). But this study shows entirely different chemical composition of leaves.

Thirty five compounds were identified accounting to $98.9 \%$ of essential oil from peel. Limonene was found to be the major constituent $(93.02 \%)$. 
Table 1: The composition of the volatile oil from leaf.

\begin{tabular}{|c|c|c|c|}
\hline Peak & RT & Name & $\%$ \\
\hline 1. & 8.152 & 4-Terpinenol & 0.19 \\
\hline 2. & 10.779 & 3-Methyl-6-(1-methylethylidene) cyclohexene & 0.44 \\
\hline 3. & 11.649 & $\beta$-Elemene & 0.74 \\
\hline 4. & 12.127 & $\beta$-Caryophyllene & 16.89 \\
\hline 5. & 12.639 & $\alpha$-Caryophyllene & 2.48 \\
\hline 6. & 12.963 & -- & 0.19 \\
\hline 7. & 13.287 & 1-Ethenyl-1-methyl-2-(1-methylethenyl)-4-(1-methylethylidene) cyclohexane & 2.66 \\
\hline 8. & 13.560 & -- & 0.52 \\
\hline 9. & 13.645 & -- & 0.91 \\
\hline 10. & 14.105 & (Z)-1,3-Bis-(2-cyclopropyl,2-methyl cyclopropyl)-but-2-en-1-one & 0.38 \\
\hline 11. & 14.174 & -- & 1.27 \\
\hline 12. & 14.361 & 1-Methylene-2b-hydroxymethyl-3,3-dimethyl-4b-(3-methylbut-2-enyl)-cyclohexane & 0.28 \\
\hline 13. & 14.481 & (-)-Spathulenol & 9.32 \\
\hline 14. & 14.566 & Caryophyllene oxide & 1.03 \\
\hline 15. & 14.685 & Viridiflorol & 0.75 \\
\hline 16. & 14.839 & -- & 0.40 \\
\hline 17. & 14.924 & Humulene 1,2-epoxide & 1.02 \\
\hline 18. & 15.163 & $\alpha$-Bergamotene & 0.74 \\
\hline 19. & 15.316 & $\tau$-Cadinol & 3.16 \\
\hline 20. & 15.521 & $\alpha$-Cadinol & 2.51 \\
\hline 21. & 15.760 & -- & 0.18 \\
\hline 22. & 16.340 & Cyclopentaneundecanoic acid, methyl ester & 0.17 \\
\hline 23. & 16.408 & 1,3-Bis-(2-cyclopropyl,2-methyl cyclopropyl)-but-2-en-1-one & 0.33 \\
\hline 24. & 16.681 & -- & 0.59 \\
\hline 25. & 17.364 & -- & 0.17 \\
\hline 26. & 17.858 & 6,10-Dimethyl-2-undecanone & 1.35 \\
\hline 27. & 18.848 & 15-Methyl- hexadecanoic acid, methyl ester & 0.24 \\
\hline 28. & 19.103 & 3,5,11,15-Tetramethyl-1-hexadecen-3-ol & 0.26 \\
\hline 29. & 20.093 & 3,7,11-Trimethyl-3-hydroxy-6,10-dodecadien-1-yl acetate & 0.29 \\
\hline 30. & 20.878 & Oxalic acid, allyl pentadecyl ester & 0.22 \\
\hline 31. & 21.014 & Citronellol & 28.26 \\
\hline 32. & 21.321 & 2-n-Hexylcyclopentanone & 2.22 \\
\hline 33. & 21.441 & 3,7-Dimethyl-6-octen-1-ol, formate & 0.71 \\
\hline 34. & 21.662 & -- & 0.28 \\
\hline 35. & 27.872 & 2,6-Dimethyl-1,5-heptadiene & 0.29 \\
\hline 36. & 32.034 & -- & 11.69 \\
\hline 37. & 32.904 & 1-Bromo-4-bromomethyl decane & 2.43 \\
\hline 38. & 33.041 & -- & 1.93 \\
\hline 39. & 33.382 & -- & 0.31 \\
\hline 40. & 33.587 & -- & 0.79 \\
\hline 41. & 33.740 & -- & 0.27 \\
\hline 42. & 33.945 & -- & 1.14 \\
\hline
\end{tabular}

-- Unidentified

Table 2: The composition of the volatile oil from rind.

\begin{tabular}{|c|c|c|c|}
\hline Peak & RT & Name & $\%$ \\
\hline 1. & 4.490 & $\alpha$-Pinene & 0.41 \\
\hline 2. & 4.605 & -- & 0.24 \\
\hline 3. & 4.783 & -- & 0.25 \\
\hline 4. & 5.184 & $\beta$-Phellandrene & 0.43 \\
\hline 5. & 5.298 & $\beta$-Pinene & 2.25 \\
\hline 6. & 5.438 & $\beta$ Myrcene & 2.06 \\
\hline 7. & 6.265 & D-Limonene & 89.04 \\
\hline 8. & 6.494 & $\beta$-Ocimene & 0.33 \\
\hline 9. & 6.946 & Ethyl 2-(5-methyl-5-vinyltetrahydrofuran-2-yl)propan-2-yl carbonate & 0.09 \\
\hline 10. & 7.226 & -- & 0.08 \\
\hline 11. & 7.430 & Linalool & 0.49 \\
\hline 12. & 7.856 & -- & 0.11 \\
\hline 13. & 8.098 & cis-p-Mentha-2,8-dien-1-ol & 0.11 \\
\hline 14. & 8.842 & Terpinen-4-ol & 0.11 \\
\hline 15. & 9.058 & L- $\alpha$-Terpineol & 0.39 \\
\hline 16. & 9.141 & -- & 0.24 \\
\hline 17. & 9.733 & Neral & 0.18 \\
\hline 18. & 10.140 & Geranial & 0.13 \\
\hline 19. & 11.100 & -- & 0.06 \\
\hline 20. & 11.139 & 2-Carene & 0.06 \\
\hline 21. & 11.896 & -- & 0.06 \\
\hline 22. & 11.972 & -- & 0.05 \\
\hline
\end{tabular}

-- Unidentified 


\begin{tabular}{|c|c|c|c|}
\hline 23. & 12.347 & Caryophyllene & 0.20 \\
\hline 24. & 12.475 & Bicyclo[4.4,0]dec-1-ene,2-isopropyl-5-methyl-9-methylene & 0.10 \\
\hline 25. & 12.659 & $\gamma$-Muurolene & 0.03 \\
\hline 26. & 12.761 & -- & 0.03 \\
\hline 27. & 13.143 & $\beta$-Copaene & 1.76 \\
\hline 28. & 13.327 & -- & 0.24 \\
\hline 29. & 13.384 & $\gamma$-Muurolene & 0.05 \\
\hline 30. & 14.479 & Hexadecane & 0.09 \\
\hline 31. & 16.718 & Octadecane & 0.08 \\
\hline 32. & 17.838 & 7,9,Di-tert-butyl-1-oxaspiro(4,5)eca-6,9-diene-2,8-dione & 0.11 \\
\hline 33. & 18.741 & Eicosane & 0.05 \\
\hline
\end{tabular}

Table 3: Linear retention index of the compounds identified from leaf and rind.

\begin{tabular}{|c|c|c|c|c|}
\hline $\mathbf{S N}$ & LRI & Sample Name & Leaf & Rind \\
\hline 1. & - & 4-Terpinenol & + & \\
\hline 2. & 97 & $\alpha$-Pinene & & + \\
\hline 3. & 1014 & $\beta$ Myrcene & & + \\
\hline 4. & 1029 & Geranial & & + \\
\hline 5. & 1033 & $\beta$-Ocimene & & + \\
\hline 6. & 1044 & $\beta$-Pinene & & + \\
\hline 7. & 1061 & Ethyl 2-(5-methyl-5-vinyltetrahydrofuran-2-yl)propan-2-yl carbonate & & + \\
\hline 8. & 1064 & $\beta$-Elemene & + & \\
\hline 9. & 1071 & 2-n-Hexylcyclopentanone & + & \\
\hline 10. & 1072 & L- $\alpha$-Terpineol & & + \\
\hline 11. & 1075 & 3-Methyl-6-(1-methylethylidene) cyclohexene & + & \\
\hline 12. & 1077 & Terpinen-4-ol & & + \\
\hline 13. & 1078 & D-Limonene & & + \\
\hline 14. & 1135 & 3,7-Dimethyl-6-octen-1-ol, formate & + & \\
\hline 15. & 1315 & 15-Methyl- hexadecanoic acid, methyl ester & + & \\
\hline 16. & 1486 & 1-Bromo-4-bromomethyl decane & + & \\
\hline 17. & 1519 & Caryophyllene & + & \\
\hline 18. & 1532 & Hexadecane & & + \\
\hline 19. & 1541 & Caryophyllene oxide & + & \\
\hline 20. & 1541 & Bicyclo[4.4,0]dec-1-ene,2-isopropyl-5-methyl-9-methylene & & + \\
\hline 21. & 1542 & $\tau$-Cadinol & + & \\
\hline 22. & 1543 & Viridiflorol & + & \\
\hline 23. & 1546 & $\alpha$-Cadinol & + & \\
\hline 24. & 1548 & $\beta$-Caryophyllene & + & \\
\hline 25. & 1558 & (-)-Spathulenol & + & \\
\hline 26. & 1561 & $\alpha$-Caryophyllene & + & \\
\hline 27. & 1564 & 6,10-Dimethyl-2-undecanone & + & \\
\hline 28. & 1666 & Octadecane & & + \\
\hline 29. & 1694 & Eicosane & & + \\
\hline 30. & 1724 & 1,3-Bis-(2-cyclopropyl,2-methyl cyclopropyl)-but-2-en-1-one & + & \\
\hline 31. & 1785 & Oxalic acid, allyl pentadecyl ester & + & \\
\hline 32. & 1820 & 3,5,11,15-Tetramethyl-1-hexadecen-3-ol & + & \\
\hline 33. & 1855 & 7,9,Di-tert-butyl-1-oxaspiro(4,5)eca-6,9-diene-2,8-dione & & + \\
\hline 34. & 2030 & Citronellol & + & \\
\hline 35. & 2055 & 3,7,11-Trimethyl-3-hydroxy-6,10-dodecadien-1-yl acetate & + & \\
\hline
\end{tabular}

The other compounds identified were myrcene, $\alpha$-pinene, sabinene, linalool, octylacetate, neral, geranial, germacrene $\mathrm{D}$, citropten, 4-methyl-2-pentanone, butyl acetate, $\beta$-pinene, $(E)-\beta$ ocimene, nonanol, cis-limonene oxide, citronellal, $\alpha$-terpineol, geraniol, decanal, undecanal, $\delta$-elemene, neryl acetate, geranyl acetate, $\beta$-elemene, dodecanal, $\beta$-caryophyllene, $\alpha$-salimene, germacrene $\mathrm{B}$, nootkatone, hexadecanal, isobergaptene, osthole and auraptene (Bordoloi et al., 1999). Results of this study also showed limonene as the major constituent accounting to $89.04 \%$. But the minor constituents were different in contrast to the earlier reports.

Citrus peels are rich sources of biologically active antimicrobial compounds like flavanones and polymethoxylated flavones, which are not found in other trees. The difference in the constitution may be due to the genetic and ecological variation of the plants. They are mostly used in food industries and also used as flavoring agents.It is also known to possess anti-inflammatory and anti-cancer properties. Constituents, such as simple sugars, carotenoids, vitamin $\mathrm{C}$, flavonoids, limonoids, folic acid, fibres and potassium are good for human health. Major portion of citrus fruits produced are processed into juices, jams and concentrates (Francis and Hoang, 2015).

\section{CONCLUSION}

Citrus fruits are the most widely available and maximum consumed fruits. It has so many medicinal properties and very less toxic effect. The detection of compounds may be helpful in the study and association of various medicinal properties in the extract of leaves and fruit rind of Citrus maxima (Burm.) Merr. from Dakshina Kannada. 


\section{REFERENCE}

Adams RP. 1995. Identification of Essential Oil Components by Gas Chromatography/ Mass Spectrometry. Carol Stream: Allured Publ Corp.

Bordoloi AK, Pathak MG, Sperkova J, Leclerq PA. Volatile constituents of the fruit peel oil of Citrus maxima (J. Burman) Merrill. From Northeast India. J Essent Oil Res, 1999; 11:629-632.

Bortahnkur SK. Postnatal care of women in traditional system in Assam. Ethnobotany, 1996; 8:51-55.

Chaudhari RHN, Pal DC. Preliminary observation on the ethnobotany of Midnapore district, West Bengal, 1975-76; 10-11:51-53.

Chopra RN, Nayar SL, Chopra IC. 1956. Glossary of Indian Medicinal Plans, New Delhi: National Institute of Science Communication and Information Resources 68.

Dagar HS, Dagar JC. Ethnobotanical studies of the Nicobarese of Chowra Island of Nicobar group of Islands. J Econ Tax Bot Addl Ser, 1996; 12:381-388.

Droby S, Eick A, Macarisin D, Cohen L, Rafael G, Stange R, McColum G, Dudai N, Nasser A, Wisniewski M, Role of Citrus Volatiles in Host Recognition, Germination and Growth of Penicillium digitatum and Penicillium italicum. Postharvest Biology and Technology, 2008; 49( 3):386-96.

Francis GW, Hoang BYT. Changes in the Composition of Aromatherapeutic Citrus Oils during Evaporation. Evidence-Based Complementary and Alternative Medicine, 2015; Article ID 421695, 6 pages.

Fuselli SR, de la Rosa SBG, Eguaras MJ, Fritz R. Chemical Composition and Antimicrobial Activity of Citrus Essences on Honeybee Bacterial Pathogen Paenibacillus larvae, the Causal Agent of American Foul- brood. World Journal of Microbiology and Biotechnology, 2008; 24(10): 2067-72.

Javed S, Javaid A, Nawaz S, Saeed MK, Mahmood Z, Siddiqui SZ, Ahmad R. Phytochemistry, GC-MS Analysis, Antioxidant and Antimicrobial Potential of Essential Oil From Five Citrus Species. Journal of Agricultural Science, 2014; 6(3):201-8.

Kirbaşlar FG, Tavman A, Dülger B, Türker G, Antimicrobial Activity of Turkish Citrus Peel Oils. Pakistan Journal of Botany, 2009; 41(6):3207- 12

Nadakarni AK. 1954. Indian Material Medica. 3rd Ed, Bombay: Popular Book Depot, 45-49.

Nigam SS, Dutt S. Chemical examination of essential oil derived from leaves of Citrus decumana Murr. Indian Saop J, 1945; 11:225-229.

Nigam SS, Kumari GL. Application of physical methods to the analysis of essential oils. Part 1: Chromatography. Perfum Essent Oil Res, $1962 ; 53: 529-536$.
Okunowo WO, Oyedeji LO, Afolabi O, Matanmi E. Essential Oil of Grape Fruit (Citrus paradisi) Peels and Its Antimicrobial Activities. American Journal of Plant Sciences, 2013; 4:1-9.

Oliveira ACS, Rabelo MZJ, Bispo RDIF, Pereira CA, Cardoso AO. The antimicrobial effects of Citrus limonum and Citrus aurantium essential oils on multi-species biofilms. Braz Oral Res, 2014; 28(1):22-27

Pandey A, Kaushik A, Tiwari SK. Evaluation of antimicrobial activity and phytochemical analysis of Citrus limon. JPBMS, 2011 13(17).

Sarrou E, Chatzopoulou P, Dimassi-Theriou K and Therios I Volatile Constituents and Antioxidant Activity of Peel, Flowers and Leaf Oils of Citrus aurantium L. Growing in Greece. Molecules, 2013; 18:10639-10647.

Takaya M, Masayuki K, Shin H, Mitsuo O. Molecular approach to citrus flavonoid and limonoid biosynthesis. Food Agric Environ, 2008; $1: 22-25$

Unal MU, Ucan F, Şener A, Dincer Sadık. Research on antifungal and inhibitory effects of DL-limonene on some yeasts. Turk J Agric For, 2012; 36:576-582.

Uysal B, Sozmen F, Aktas O, Oksal BS, Kose EO. Essential Oil Composition and Antibacterial Activity of the Grapefruit (Citrus paradisi L.) Peel Essential Oils Obtained by Solvent-Free Microwave Extraction: Comparison with Hydrodistillation. International Journal of Food Science and Technology, 2011; 46:1455-61.

Vasudeva N, Sharma T. Chemical Composition and Antimicrobial Activity of Essential Oil of Citrus limettioides Tanaka Journal of Pharmaceutical Technology and Drug Research, 2012. http://www.hoajonline.com/journals/pdf/2050-120X-1-2.pdf.7pages.

Zohra HF, Rachida A, Malika M, Benali S, Samir AA, Meriem B. Chemical composition and antifungal activity of essential oils of Algerian Citrus. African Journal of Biotechnology, 2015; 14(12):1048-55.

\section{How to cite this article:}

Anupama Prasad D, Rajendra Prasad B, Krishna Prasad D, Puneeth Shetty, Sunil Kumar KN. GCMS Compositional Analysis of Essential Oil of Leaf and Fruit Rind Of Citrus maxima (Burm.) Merr. from Coastal Karnataka, India. J App Pharm Sci, 2016; 6 (05): 068-072. 